\title{
DESCRIPTION OF STUDENT'S JUNIOR HIGH SCHOOL MATHEMATICAL CONNECTION ABILITY ON THE LINEAR FUNCTION TOPIC
}

\author{
Aulia Suci Wardina ${ }^{1}$, Eyus Sudihartinih ${ }^{2}$ \\ ${ }^{1}$ Universitas Pendidikan Indonesia Indonesia, auliasuciwardina19@student.upi.edu \\ ${ }^{2}$ Universitas Pendidikan Indonesia Indonesia, eyuss84@upi.edu
}

\section{ARTICLE INFORMATION}

Received: November 18, 2019

Revised: December 26, 2019

Available online: December 31, 2019

KEYWORDS

\section{Connection, Mathematical} connection ability, Function, Junior high school

\section{CORRESPONDENCE}

\section{EYUS SUDIHARTINIH}

E-mail: eyuss84@upi.edu

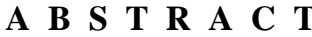

Penelitian ini bertujuan untuk mengetahui kemampuan koneksi matematis siswa SMP di Kota Bandung. Penelitian ini menggunakan metode kualitatif deskriptif dengan triangulasi data. Instrumen yang digunakan berupa tes uraian sebanyak tiga soal yang telah dikonsultasikan dengan ahli dan mengacu pada indikator kemampuan koneksi matematis. Hasil penelitian ini mendeskripsikan 1) kemampuan siswa dalam menghubungkan antar konsep matematika dengan persentase sebanyak 58,33\%, 2) kemampuan siswa dalam menghubungkan dan mengaplikasikan konsep matematika pada disiplin ilmu lain dengan persentase sebanyak 50\%,3) kemampuan siswa dalam mengaplikasikan konsep matematika untuk menyelesaikan permasalahan dalam kehidupan sehari-hari dengan persentase sebanyak 66,67\%. Hasil penelitian menunjukkan bahwa kemampuan koneksi matematis siswa SMP di Kota Bandung pada topik fungsi linear sudah cukup baik.

This research aims to determine the mathematical connection ability of junior high school students in Bandung. This research uses descriptive qualitative method with data triangulation. The instrument used in the form is test description as many as three questions that have been consulted with experts and refers to indicators of mathematical connection ability. The results of this research describe 1) the ability of students to connect between mathematical concepts with a percentage of $58.33 \%$, 2) the ability of students to connect and apply mathematical concepts in other disciplines of sciences with a percentage of $50 \%, 3)$ the ability of students to apply mathematical concepts to solving problems in daily life with a percentage of $66.67 \%$. The results showed that the mathematical connection ability of junior high school students in Bandung on the topic of linear function was good enough.

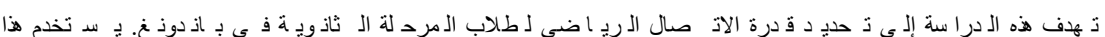

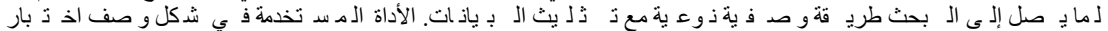

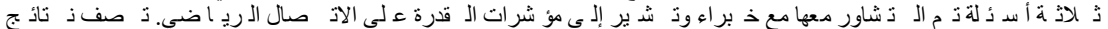

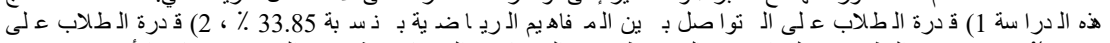

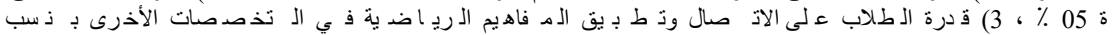

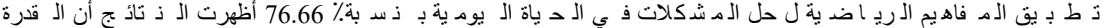

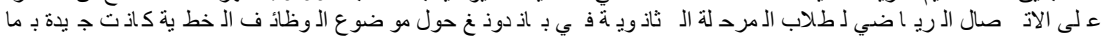
فو به الـ ك فائة

\section{INTRODUCTION}

Mathematical connection ability is the ability to find and connect between topics to solve problems in mathematics, other sciences or in daily life (Nurlissolihah et al., 2018). It is also defined as the ability to present internal and external relationship of mathematics: to connect between mathematical topics and other disciplines in daily life (Rohendi \& Dulpaja, 2013).

These are three indicators of mathematics connection ability: 1) Accepting and exploiting the relationship between ideas in mathematics; 2) Understanding how ideas in mathematics are interconnected and underlie others to produce a unified whole; and 3) Accepting and applying mathematics outside of the context of mathematics National Council of Teachers of Mathematics (NCTM) (Siregar \& Surya, 2017). 


\section{Journal of Mathematics Science and Education \\ | ISSN (Print) 2623-2375 | ISSN (Online) 2623-2383 | \\ DOI : https://doi.org/10.31540/imse.v2i1.813 \\ Penerbit : LP4MK STKIP PGRI Lubuklinggau}

Mathematical connections are important because mathematics is a unified part of various topics, from other disciplines of sciences, and problems in daily life. Without mathematical connections, students will be difficult to understand many separate mathematical concepts and procedures NCTM (Sugiman, 2008).

Mathematical connections are important because students will be encouraged to have more understanding of mathematics and also to develop their mathematical abilities if students are able to know the existing mathematical relationships (Siagian, 2016). When students can connect the mathematical ideas, their understandings will be deeper and last longer NCTM (Pranawestu \& Hidayah, 2018).

Based on previous research, there are still schools with several students who have low mathematical connection ability. The percentage of mathematical connection ability of students from one of the schools was $21.11 \%$ in connecting between mathematical concepts, $13.33 \%$ in connecting mathematics with other sciences, $32.22 \%$ in connecting mathematics with daily life (Rahmawati, Budiyono, \& Saputro, 2019).

Other research also shows that $63.69 \%$ of students in the $8^{\text {th }}$ grade of junior high school in Semarang are able to understand between mathematical topics, $23.80 \%$ are able to apply mathematics in other fields of daily life, $13.09 \%$ apply the relationship between mathematical topics with other topics (Maryanasari \& Zanthy, 2012).

Research on the $9^{\text {th }}$ grade of junior high school students at a private junior high school Muhammadiyah 22 Kisaran is still very low. 51,11\% of students can apply the concept of mathematics to solve the daily life problems and $17,78 \%$ of students can connect between mathematical concepts to solve the problem (Siregar \& Surya, 2017)

Research on the $7^{\text {th }}$ grade of junior high school students in Central Java also shows low connections score where students cannot connect concepts in a plane figure. Students cannot understand how mathematical ideas are connected to produce a coherent one. Students cannot recognize and apply mathematics in everyday life (Ramdhani, Widiyastuti, \& Subekti, 2016). Therefore, this research objective is to describe the junior high school students' mathematical connection ability on the linear function topic. 


\section{Journal of Mathematics Science and Education \\ | ISSN (Print) 2623-2375 | ISSN (Online) 2623-2383 | \\ DOI : https://doi.org/10.31540/imse.v2i1.813 \\ Penerbit : LP4MK STKIP PGRI Lubuklinggau}

\section{METHOD}

This research used a descriptive qualitative method following the research of Sudihartinih (Sudihartinih, 2018) which would describe the mathematical connection ability of students by using data triangulation (interviews, documentation, and theory). The participants of this research were three female students of the $8^{\text {th }}$ grade from several junior high schools in Bandung. Student A was from public junior high school while student $\mathrm{B}$ and student $\mathrm{C}$ were from the same private junior high school. The instruments used were description tests, documentation, researchers, and interviews.

The questions in this research have been consulted by experts namely supervisors and arranged based on mathematical connection ability indicators, which are: 1) students are able to recognize and connect relationships between mathematical ideas, 2) students are able to connect and apply mathematical concepts in other disciplines, and 3) students are able to connect and apply mathematical concepts to problems in daily life. Those indicators are on the questions number 1, 2, and 3:

1. Given the system of linear equations the following two variables:

$$
\left.\begin{array}{r}
2 x-4 y=12 \\
x+2 y=10
\end{array}\right\}
$$

a. Sketch a graph of the two-variable linear equation system!

b. Determine the set of solutions of the two-variable linear equation system!

2. Aisyah and Nusaibah will go to Bandung using the same Argo Parahyangan train but from different places and hours. Aisyah departs from Gambir Station and Nusaibah departs from Bekasi Station. The train departs from Gambir Station at 10.30 WIB through Bekasi Station and arrives at Bandung Station at 13.30 WIB. The distance travelled by train from Gambir Station to Bekasi Station is $25.7 \mathrm{~km}$. The train moves with a speed of $55.3 \mathrm{~km} / \mathrm{hour}$. The distance travelled by train every time $(\mathrm{t})$ is $\mathrm{s}(\mathrm{t})=55.3 \mathrm{t}$.

a. How much time does the train take when the train arrives at Bekasi Station?

b. How many distances travelled by train from Gambir Station to Bandung Station?

3. A salesperson in the city of Bandung receives a salary Rp 40,074,960 per year plus 5\% commission from total sales during the year with $\mathrm{y}$ stating the annual salary accumulation and $\mathrm{x}$ stating total sales each year.

a. Determine the general form of the straight line equation (a form of the linear function)!

b. How much the salesperson salary for a year if the total sales are Rp 5,000,000? 


\section{Table 1.}

Scoring Rubric

\begin{tabular}{|c|c|c|}
\hline Indicators & Students Responses to Questions & Score \\
\hline \multirow{5}{*}{$\begin{array}{l}\text { Students are able to } \\
\text { recognize and connect } \\
\text { relationships between } \\
\text { mathematical ideas. }\end{array}$} & No answers & 0 \\
\hline & The answers do not match to questions & 1 \\
\hline & $\begin{array}{l}\text { Able to answer questions but have not } \\
\text { been able to connect yet }\end{array}$ & 2 \\
\hline & $\begin{array}{l}\text { Able to answer questions, able to connect, } \\
\text { but the final results obtained are wrong }\end{array}$ & 3 \\
\hline & $\begin{array}{l}\text { Able to answer questions, able to connect, } \\
\text { and the final results obtained are correct }\end{array}$ & 4 \\
\hline \multirow{5}{*}{$\begin{array}{l}\text { Students are able to connect } \\
\text { and apply mathematical } \\
\text { concepts to other disciplines } \\
\text { of sciences }\end{array}$} & No answers & 0 \\
\hline & The answers do not match to questions & 1 \\
\hline & $\begin{array}{l}\text { Able to answer questions but have not } \\
\text { been able to connect yet }\end{array}$ & 2 \\
\hline & $\begin{array}{l}\text { Able to answer questions, able to connect, } \\
\text { but the final results obtained are wrong }\end{array}$ & 3 \\
\hline & $\begin{array}{l}\text { Able to answer questions, able to connect, } \\
\text { and the final results obtained are correct }\end{array}$ & 4 \\
\hline \multirow{5}{*}{$\begin{array}{l}\text { Students are able to connect } \\
\text { and apply mathematical } \\
\text { concepts to problems in daily } \\
\text { life }\end{array}$} & No answers & 0 \\
\hline & The answers do not match to questions & 1 \\
\hline & $\begin{array}{l}\text { Able to answer questions but have not } \\
\text { been able to connect yet }\end{array}$ & 2 \\
\hline & $\begin{array}{l}\text { Able to answer questions, able to connect, } \\
\text { but the final results obtained are wrong }\end{array}$ & 3 \\
\hline & $\begin{array}{l}\text { Able to answer questions, able to connect, } \\
\text { and the final results obtained are correct }\end{array}$ & 4 \\
\hline
\end{tabular}

To calculate the percentage of the total score from each problem-solving indicator $\left(P_{k}\right)$ use:

$$
P_{k}=\frac{\text { Obtaining student scores on each indicator }}{\text { Maximum score on each indicator }} \times 100 \%
$$

With the following qualifications as shown in Table 2 below:

Table 2.

Qualifications of Mathematical connection ability in each indicator

\begin{tabular}{cl}
\hline Percentage & \multicolumn{1}{c}{ Qualifications } \\
\hline $85 \leq P_{k} \leq 100$ & Very Good \\
$70 \leq P_{k} \leq 84,99$ & Good \\
$55 \leq P_{k} \leq 69,99$ & Good Enough \\
$40 \leq P_{k} \leq 54,99$ & Less \\
$0 \leq P_{k} \leq 39,99$ & Very Less \\
\hline
\end{tabular}




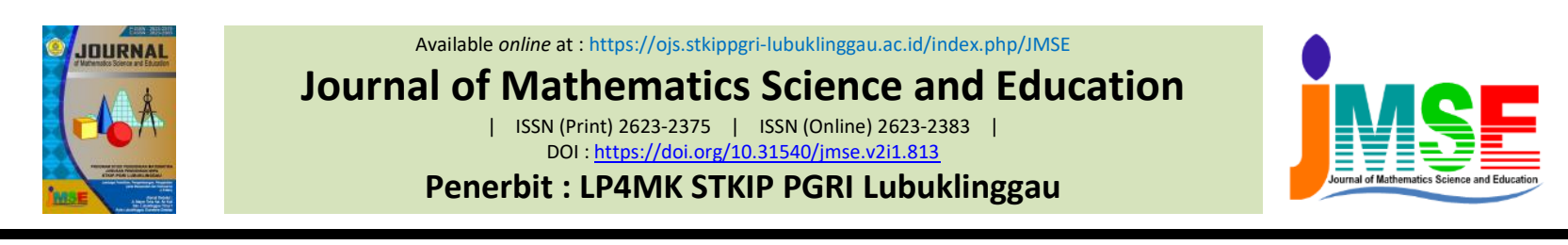

\section{RESULT AND DISCUSSION}

The instrument was tested by student $\mathrm{A}, \mathrm{B}$, and $\mathrm{C}$ after they return from the school with allocation time thirty minutes at the two different places as the following:

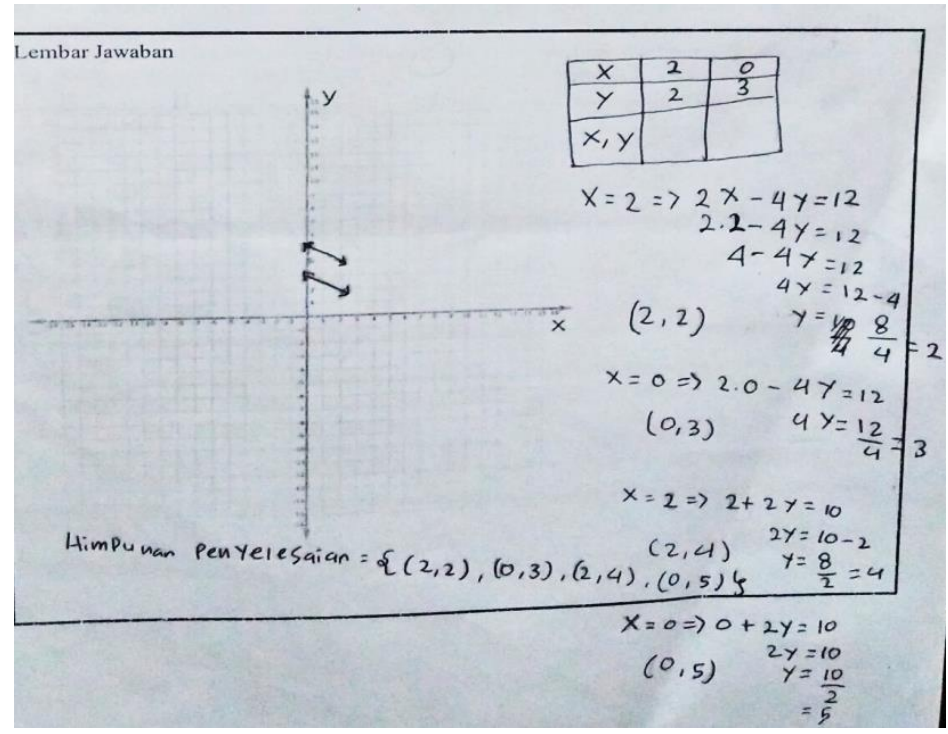

Figure 1. The result of student $A$ in number 1

Based on Figure 1 above, the answers from student $\mathrm{A}$ in number 1 it is known that the student has not been able to make a suitable graph from the existing equation system and has not been able to connect the relationship between the intersection points of two lines with the set of solutions. Students are also still wrong in algebraic operations and the determination of the intersection of the equation system.

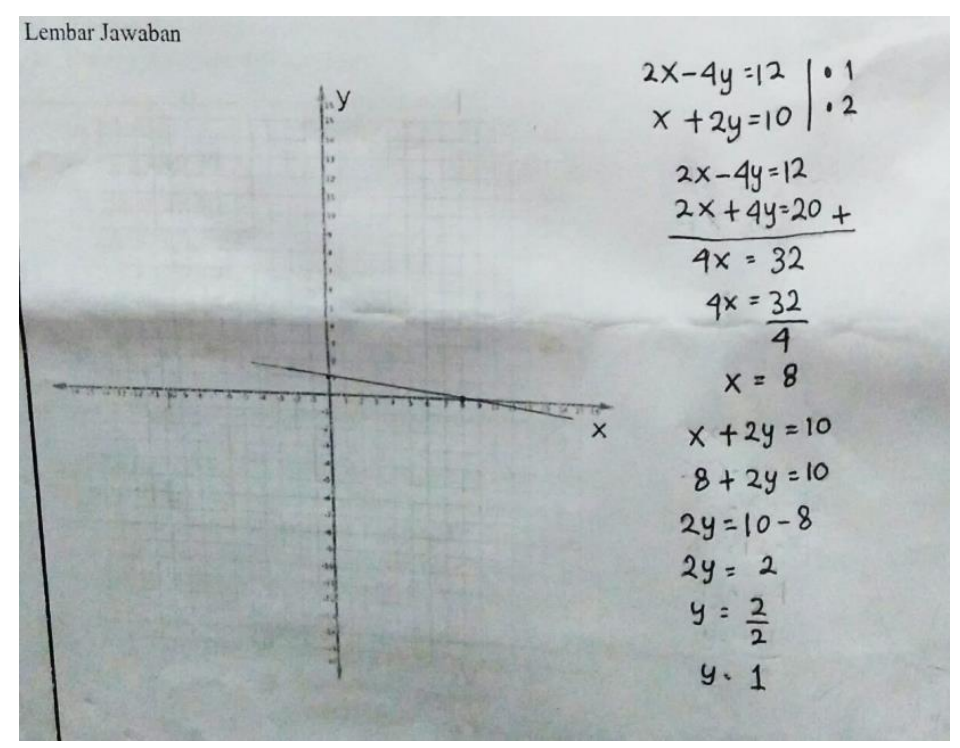

Figure 2. The result of student $B$ for number 1 


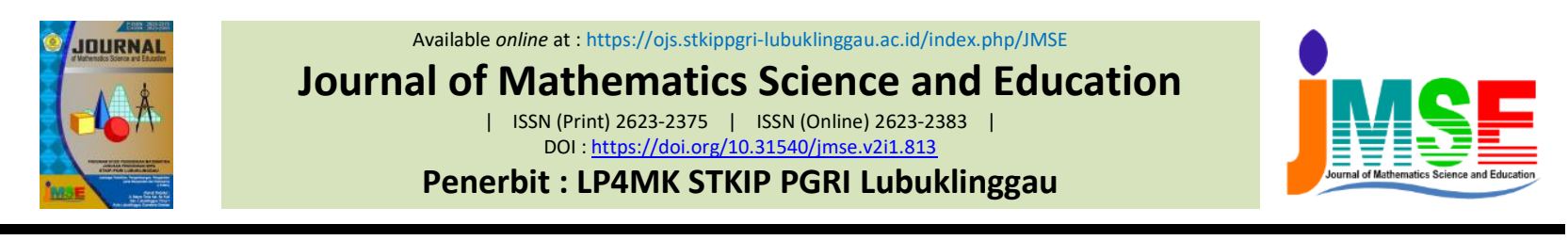

Based on Figure 2, the answer to question number 1 by student $B$ it is known that student $B$ has been able to link between algebraic concepts to determine the solution of the equation system but is still wrong in sketching the graph.

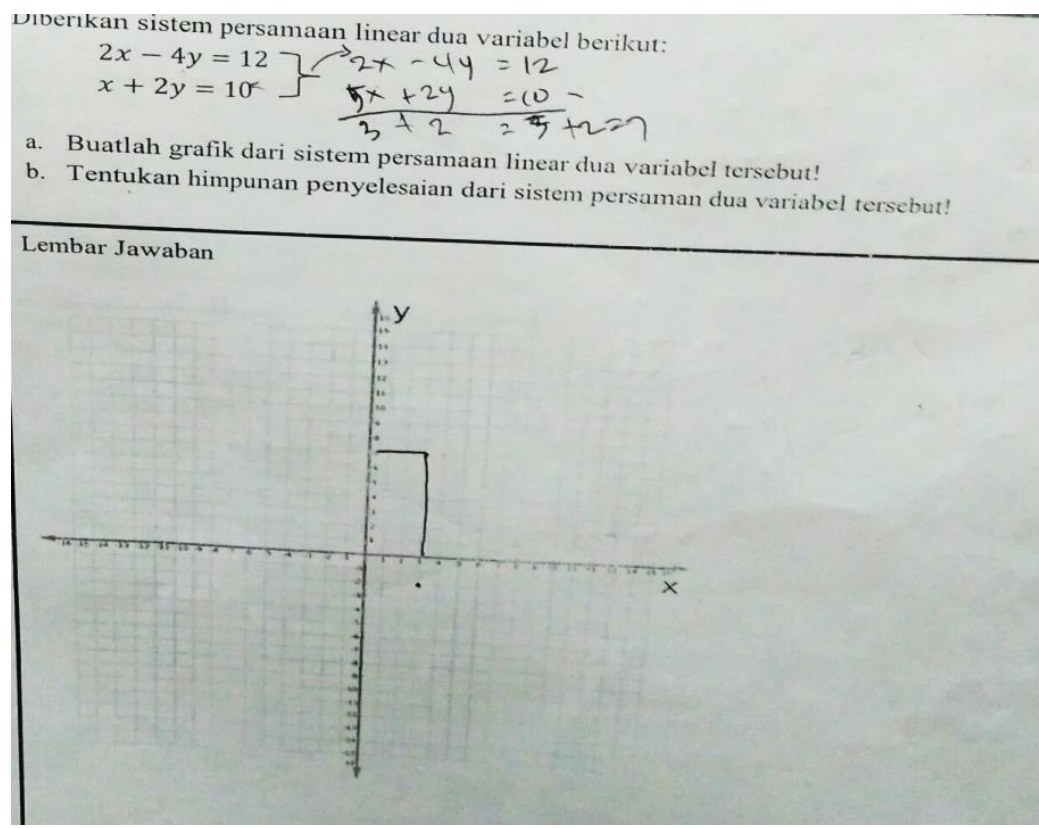

Figure 3. The result of student $\mathrm{C}$ for number 1

From Figure 3, it is known that $\mathrm{C}$ students have not been able to find a solution of the given two-variable linear equation system, linking the intersection of the $\mathrm{x}$-axis and the $\mathrm{y}$-axis in sketching the graph and determining the set of solutions.

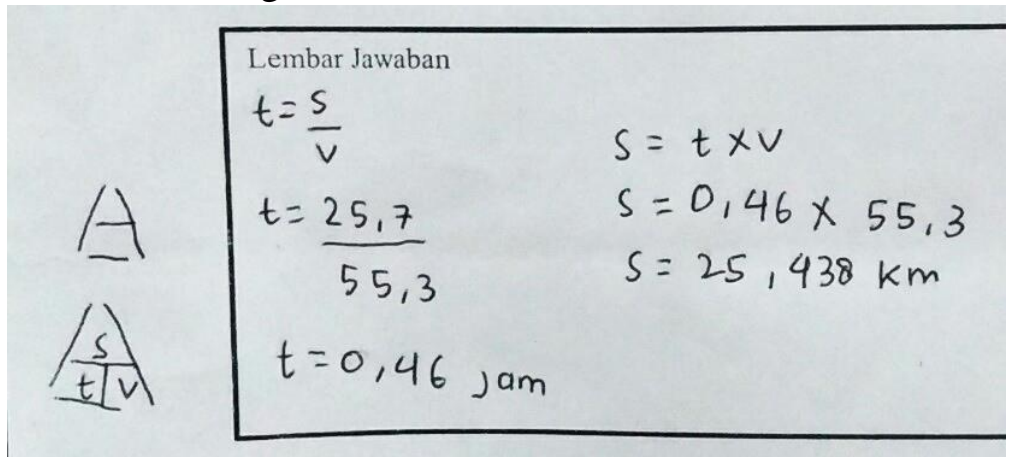

Figure 4. The result of student A for number 2

Based on Figure 4, student A has been able to answer question number 2 correctly, but students have not been able to link the topics in physics (distance, speed, and time) with mathematical topics about linear functions by substituting them into the form of functional equations. 

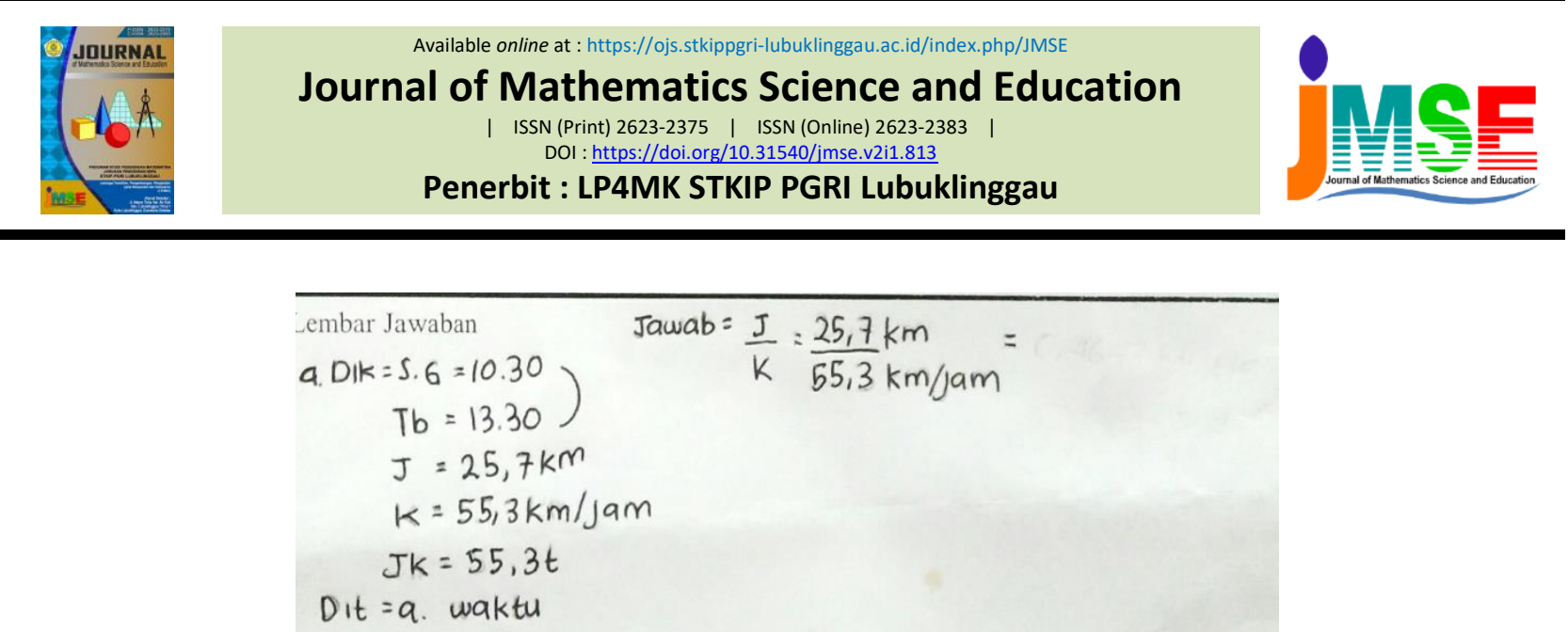

Figure 5. The result of student $B$ for number 2

Based on Figure 5, student B has not been able to answer the question completely and only uses the topic of physics and does not relate it to topics in mathematics where there is a general form of the function to find travel time and distance travelled.

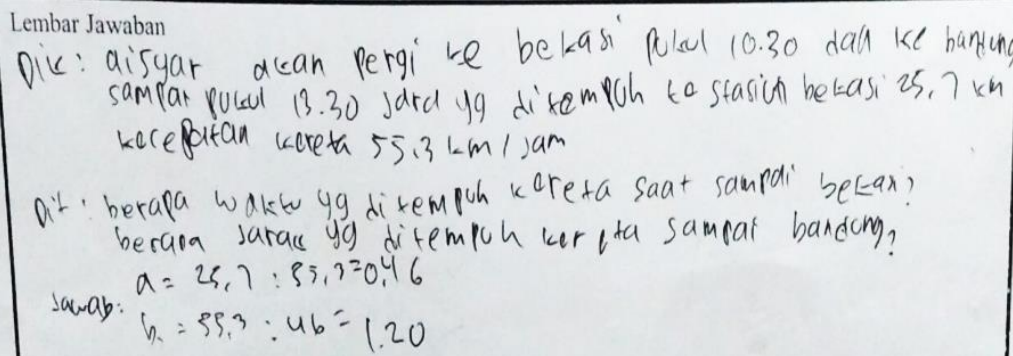

Figure 6. The result of student $\mathrm{C}$ for number 2

Student $\mathrm{C}$ is able to answer question number 2 point correctly but student $\mathrm{C}$ has not been able to associate concepts with physics with mathematical concepts (using the given function equation) to obtain solutions.

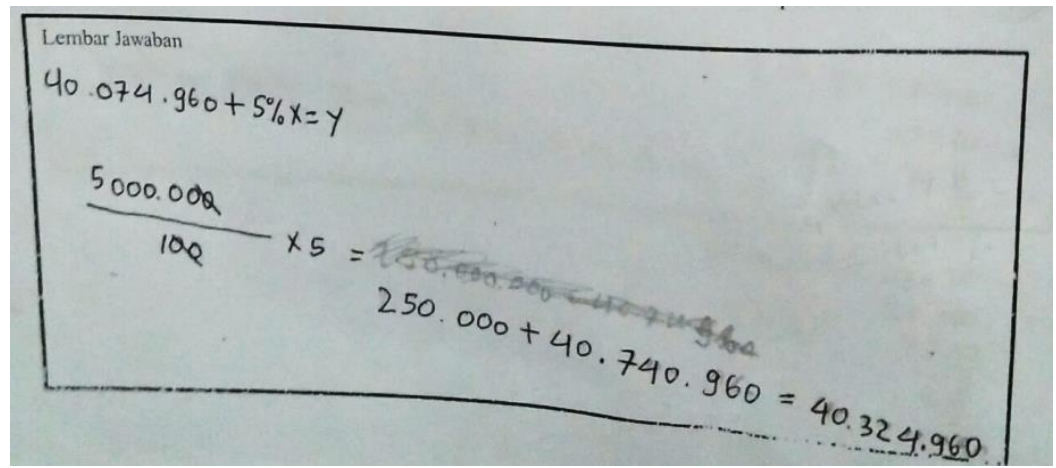

Figure 7. The result of student A for number 3

From Figure 7, it is known that student $\mathrm{A}$ has been able to determine the general form of a function of story problems related to daily life and is able to solve solutions correctly, but it was wrong when she wrote the number of 40,740,960 must be 40,074,960. 

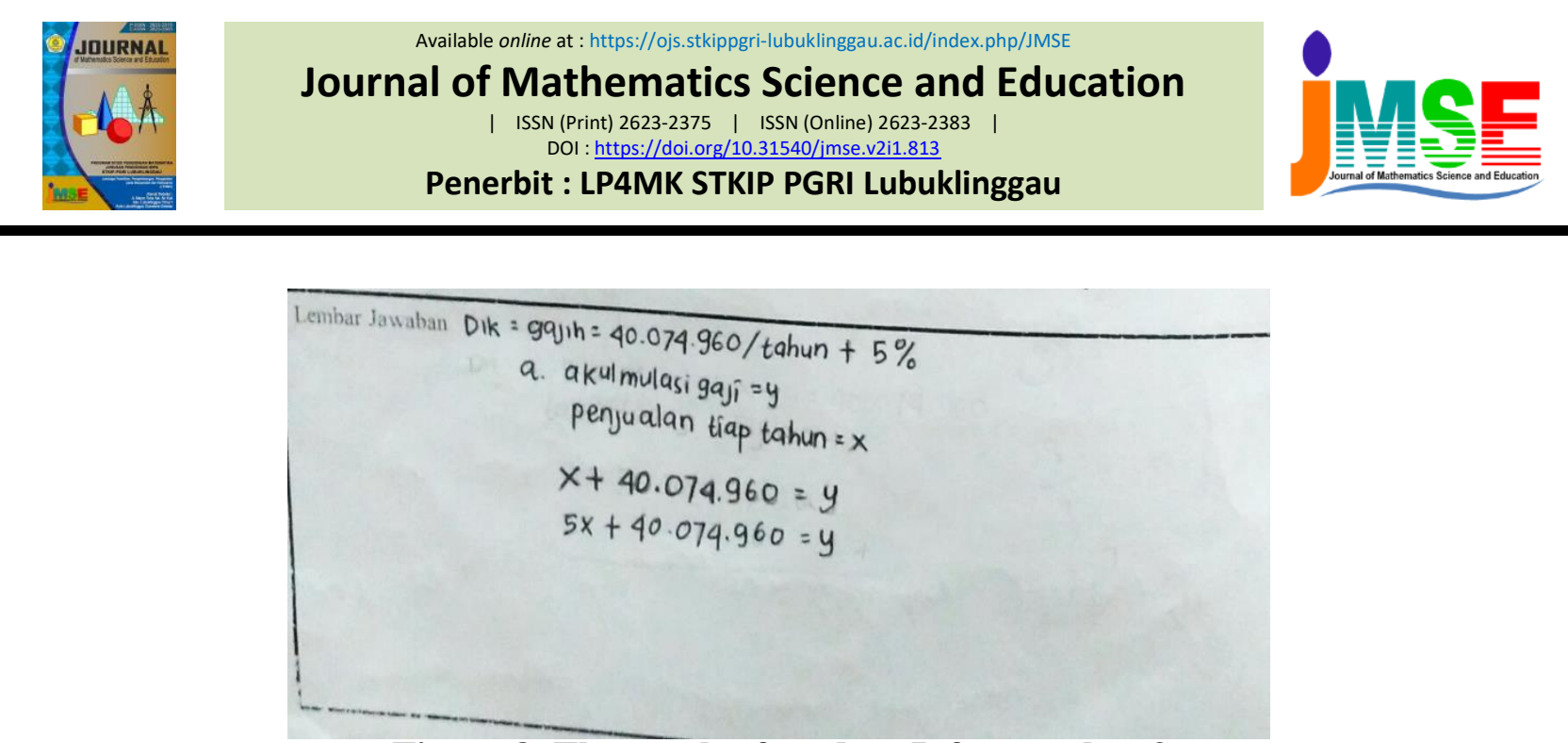

Figure 8. The result of student $B$ for number 3

From Figure 8, it was found that student B was able to connect problems in everyday life into mathematical topics, but there were still not complete yet in writing the form of its function so that it did not get the correct final solution.

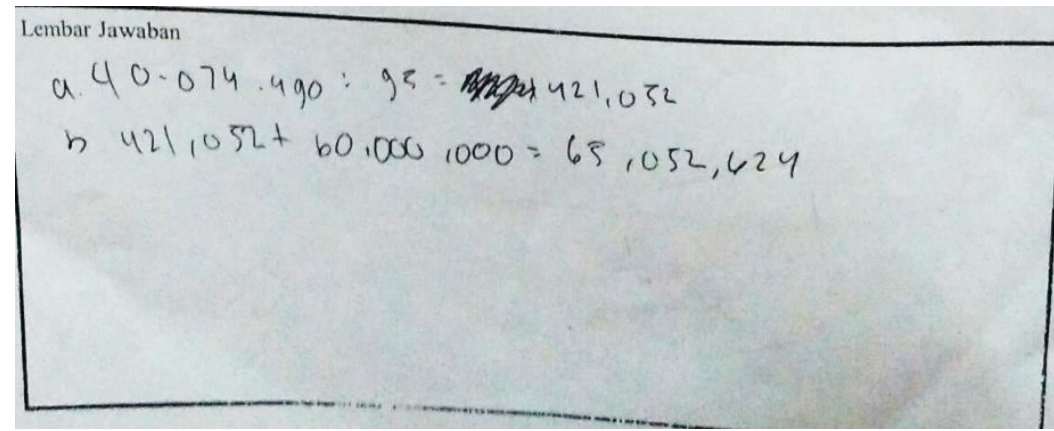

Figure 9. The result of student $\mathrm{C}$ for number 3

From figure 9, student $\mathrm{C}$ has not been able to connect the problems that exist in daily life into existing mathematical topics. The interview result will be presented as follow:

1. Student A

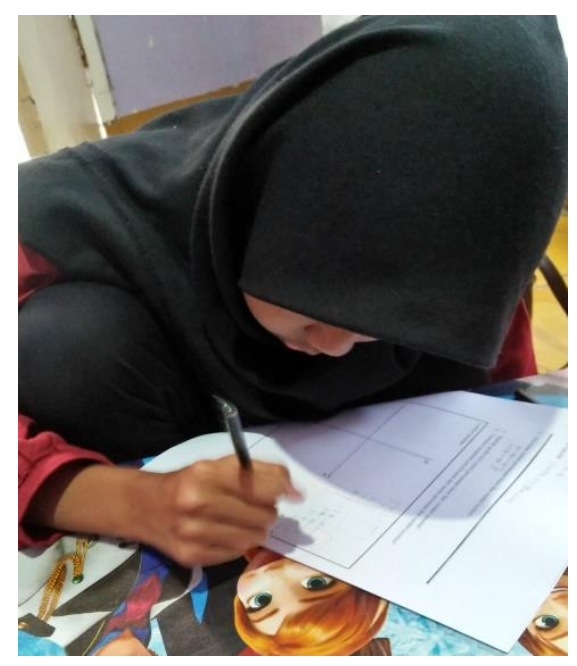

Figure 10. Student $A$ is doing a test in the Researcher's boarding house 


\section{Available online at : https://ojs.stkippgri-lubuklinggau.ac.id/index.php/JMSE \\ Journal of Mathematics Science and Education \\ ISSN (Print) 2623-2375 | ISSN (Online) 2623-2383 | \\ DOI : https://doi.org/10.31540/imse.v2i1.813 \\ Penerbit : LP4MK STKIP PGRI Lubuklinggau}

Researcher: "How to answer question number 1?"

Student A: "How could it be? First, I have to sketch the graph and then let $\mathrm{x}$ be an example."

Researcher: "And then, what's next?"

Student A: "We determined the set solution"

Researcher: "If we have done to determine the set solution, what's next?"

Student A: "Nothing."

Researcher: "So we have a set solution, what is it?"

Student A: "We have $(2,2),(0,3),(2,4)$, and $(0,5)$ "

Researcher: "Okay, are you sure with the answer? Would you add or cut the answer?"

Student A: "I'm sure, hehe"

Researcher: "For number two, what's your idea to answer it?"

Student A: "For number two, to find the time, we have known the value of distance and velocity so it's not making me headache so much and to find the value of distance it's easy enough because we have known the time from the answer before."

Researcher: "Has the time known before?"

Student A: "Yes, it has."

Researcher: "From where?"

Student A: "From..., distance divided by velocity."

Researcher: "Oh there. How could you know the formula?"

Student A: "From here." (While pointing to the triangle and there's formula about distance, velocity and time).

Researcher: "For number 3, what's the idea?"

Student A: "First, we sketch a straight line and then we substitute. For example, the salary of the salesperson for a year, we have to know how much five percents and then we sum it to his salary."

\section{Student B}

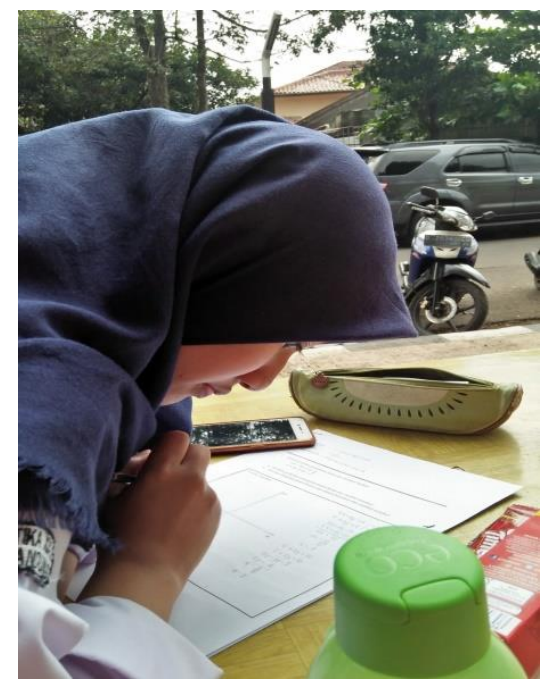

Figure 11. Student $B$ is doing a test in the garden

Researcher: "Assalamu'alaikum, Student B, how did you answer the problem ?"

Student B: "It makes me a headache, Miss."

Researcher: "Which number that makes you being a headache?" 


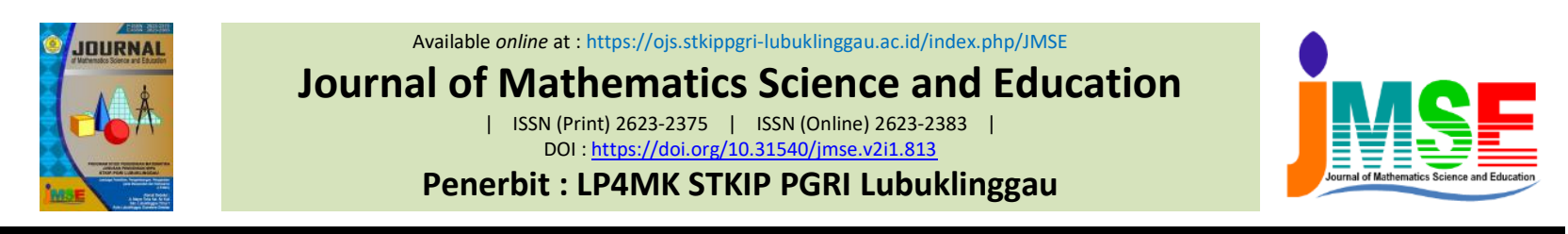

Student B: "Number two."

Researcher: "How was the number one?"

Student B: "Number one was easy enough. Number three was so hard for me."

Researcher: "Did you have an idea to answer those questions from number one till the end?"

Student B: "Number one we have to look for $\mathrm{x}$ and $\mathrm{y}$ values and then we sketch on the graph. For number two I didn't have any idea yet, Miss."

Researcher: "Didn't have any idea?"

Student B: "I forgot, Miss."

Researcher: "For number three?"

Student B: "Dizzy, complicated."

Researcher: "From three questions, which is the most difficult?"

Student B: "Number two."

Researcher: "Okay"

3. Student C

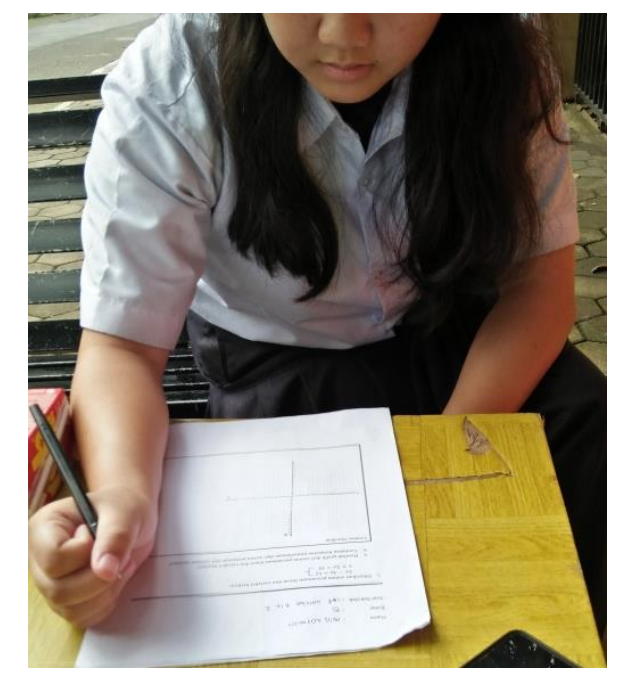

Figure 12. Student $\mathrm{C}$ is doing a test in the garden

Researcher: "Okay, good afternoon, Student C. How was your day after answering the questions?"

Researcher: "Can you answer it? Is there any problem you couldn't answer?"

Student C: "I don't understand algebra and linear. It's so dizzy, Miss"

Researcher: "Do you have an idea to solve the problems?"

Student C: "I'm confused, Miss. I have to be reminded by friends who she can to solve the other problem because I might be forgotten."

Researcher: "Which is the most difficult one?"

Student C: "Number one which there is $2 x-4 y$, Miss."

Researcher: "Hm... right. Did you study before?"

Student C: "Not yet, Miss. Just that time."

Researcher: "When?"

Student C: "Before the exam. Because I still didn't understand, forgot and confused if there are $\mathrm{x}$ and y. It makes me a headache."

Researcher: "Okay, thank you very much."

Student C: "You're welcome, Miss." 


\section{Journal of Mathematics Science and Education \\ | ISSN (Print) 2623-2375 | ISSN (Online) 2623-2383 | \\ DOI : https://doi.org/10.31540/imse.v2i1.813 \\ Penerbit : LP4MK STKIP PGRI Lubuklinggau}

The result shows that student's junior high school mathematical connection on the $8^{\text {th }}$ grade in Bandung City was good enough. The most of students can't connect mathematical concepts to other disciplines of sciences (with the percentage is only 50\%) because they asked the question with formula (triangle of distance, velocity, and time) and didn't ask with using the linear function equation which has known but in other indicators, they have a better score than indicator 2 and the categories were good enough. Based on the instruments that have been tested obtained student scores on each indicator of mathematical connection ability with sequential numbers:

1) When a student is able to connect mathematical topics? Answer: Student A scores 2, student B scores 3, dan student C scores 2.

2) When a student is able to connect mathematical topics with other topics of sciences? Answer: Student A scores 2, student B scores 2, dan student C scores 2.

3) When students are able to solve problems in daily life by connecting to mathematical topics?

Answer: Student A scores 4, student B scores 3, dan student C scores 1.

We can see that the score of indicator 2 is lower than the indicator else. The score of indicator 2 is only 6 from the total maximum score is 12 . It was half of the total maximum score with the details on point 2) which is each student get score 2 . There are 2 students get score 2 and 1 student gets score 1 in indicator 1 . In indicator 3, 1 student gets score 4, 1 student gets score 3, and 1 student gets score 1. The summary and percentages of the score on each indicator of mathematical connection ability on 3 problems of the test in Table 3 below:

Table 3.

Percentages of mathematical connection ability

\begin{tabular}{lcccc}
\hline \multicolumn{1}{c}{ Indicators } & $\begin{array}{c}\text { Total of } \\
\text { Student } \\
\text { Score }\end{array}$ & $\begin{array}{c}\text { Total of } \\
\text { Maximum } \\
\text { Score }\end{array}$ & Percentage & Category \\
\hline $\begin{array}{l}\text { Students are able to recognize } \\
\text { and connect relationships } \\
\text { between mathematical ideas. }\end{array}$ & 7 & 12 & 58,33 & $\begin{array}{c}\text { Good } \\
\text { Enough }\end{array}$ \\
$\begin{array}{l}\text { Students are able to connect } \\
\text { and apply mathematical } \\
\text { concepts to other disciplines of } \\
\text { sciences }\end{array}$ & 6 & 12 & 50 & Less \\
$\begin{array}{l}\text { Students are able to connect } \\
\text { and apply mathematical } \\
\text { concepts to other disciplines of } \\
\text { sciences }\end{array}$ & 8 & 12 & 66,67 & Good \\
\hline
\end{tabular}




\section{CONCLUSION}

Based on the description of the results of the research and discussion, it can be concluded that the percentage of student's junior high school mathematical connection ability in the first indicator is $58.33 \%$, the second indicator is $50 \%$, and the third indicator is $66.67 \%$ so that the mathematical connection ability with the topic of function in some Junior High School in the $8^{\text {th }}$ grade in the city of Bandung is in the good enough category.

\section{REFERENCES}

Maryanasari, R., \& Zanthy, L. S. (2012). Analisis Kemampuan Koneksi Matematis Siswa Smp Dengan Pendekatan Model- Elicitng Activities. Jurnal on Education, 01(02), 54-60.

Nurlissolihah at el. (2018). Reach mathematical connection ability by problem posing approach. $1(3), 244-247$.

Pranawestu, A., \& Hidayah, I. (2018). Analysis of Mathematical Connection Ability in Geometry at MEA Learning Based on Spatial Intelligence. Unnes Journal of Mathematics Education Research, 7(1), 86-93.

Rahmawati, D., Budiyono, \& Saputro, D. R. S. (2019). Analysis of student's mathematical connection ability in linear equation system with two variables. Journal of Physics: Conference Series, 1211(1). https://doi.org/10.1088/1742-6596/1211/1/012107

Ramdhani, M. R., Widiyastuti, E., \& Subekti, F. E. (2016). Analisis Kemampuan Koneksi Matematis Siswa Kelas Vii Smp Negeri 1 Kembaran. Prosiding Seminar Matematika Dan Pendidikan Matematika, (November), 403-414.

Rohendi, D., \& Dulpaja, J. (2013). Connected Mathematics Project (CMP) Model Based on Presentation Media to the Mathematical Connection Ability of Junior High School Student. 4(4), 17-22.

Sugiman. (2008). Koneksi Matematik Dalam Pembelajaran Matematika Di Sekolah Menengah Pertama. Pythagoras - Jurnal Pendidikan Matematika, 4(1), 56-67. https://doi.org/10.21831/pg.v4i1.687

Siagian, M. D. (2016). Kemampuan Koneksi Matematik Dalam Pembelajaran Matematika. MES (Journal of Mathematics Education and Science), 2(1), 58-67.

Siregar, N. D., \& Surya, E. (2017). Analysis of Students 'Junior High School Mathematical Connection Ability International Journal of Sciences: Analysis of Students ' Junior High School Mathematical Connection Ability. Ijsbar, 33(2), 309-320.

Sudihartinih, E. (2018). Analisis Kesalahan Siswa Dalam Konsep Titik Dan Garis Pada Bidang. Erudio Journal of Educational Innovation, 5(1), 12-18. https://doi.org/10.18551/erudio.5-1.2 